\title{
17. COMPOSITION OF DEEP-SEA SANDS FROM MARGINAL BASINS OF THE NORTHWESTERN PACIFIC
}

\author{
Patrick J. Harrold and J. Casey Moore, University of California, Santa Cruz, California
}

\begin{abstract}
Point counts of 28 deep-sea sand samples indicate lithic-rich compositions occur in the West Philippine Basin (avg. $\mathrm{Q}_{5} \mathrm{~F}_{17} \mathrm{~L}_{78}$ ), Shikoku Basin (avg. $\mathrm{Q}_{14} \mathrm{~F}_{15} \mathrm{~L}_{71}$, and $\mathrm{Q}_{16} \mathrm{~F}_{17} \mathrm{~L}_{67}$ ), and Yamato Basin (avg. $Q_{11} F_{15} L_{74}$ ), but quartz and feldspar-rich compositions occur in the Japan Basin (avg. $\mathrm{Q}_{32} \mathrm{~F}_{42} \mathrm{~L}_{26}$ ). By using ratios and ternary plots of detrital components, it is possible to separate the point-counted sands into suites derived from predominantly volcanic, sedimentary, and crystalline source terrains. The predictions of provenance made from the sedimentary residue are in reasonable agreement with major rock types exposed in the source areas of the sands.

An idealized scheme for the distribution of sand across a marginal basin complex indicates an increase in lithic fragments, volcanic rock fragments, and the ratio of plagioclase to total feldspar towards the frontal arc; and an increase in quartz, feldspar, and the ratio of metamorphic rock fragments over total rock fragments towards the continent. The data presented in this paper generally support this model.
\end{abstract}

\section{INTRODUCTION}

Different tectonic environments produce differentderived sandstone suites. Studies of sandstones in ancient geosynclinal sequences provide valuable insights for determining the nature of the tectonic environment at the time of deposition. Specifically, point counts of ancient sandstones have been widely used to infer provenance and to correlate within and between otherwise monotonous sandstone sequences (e.g., Ojakangas, 1968, 1972; Swe and Dickinson, 1970; Gilbert and Dickinson, 1970; Dickinson and Rich, 1972; McLane, 1972; Gilbert, 1973; Moore, 1973; Suppe, 1973; Galloway, 1974). Despite this abundance of composition data on ancient sandstones, few comparable studies exist on probably modern equivalents.

This paper intends to provide point-count data on deep-sea sands from marginal ocean basins which can serve as a reference for interpreting ancient geosynclinal sequences. Analyses of sands are presented whose source areas (Figure 1) include: (1) moderate amounts of volcanic exposures (Sites 293, 299), (2) large proportions of ancient deep-sea sedimentary rocks (Sites 297, 298), and (3) significant exposures of a crystalline basement terrain (Site 301). Although the percentage of rock type in each source terrain has not been defined, it is hoped to show how each of the derived sand compositions is distinguishable and generally reflects its provenance.

\section{METHODS}

Fifty-three samples from Sites 293, 297, 298, 299, and 301 were collected from visually observed coarsergrained intervals in the recovered cores. From these

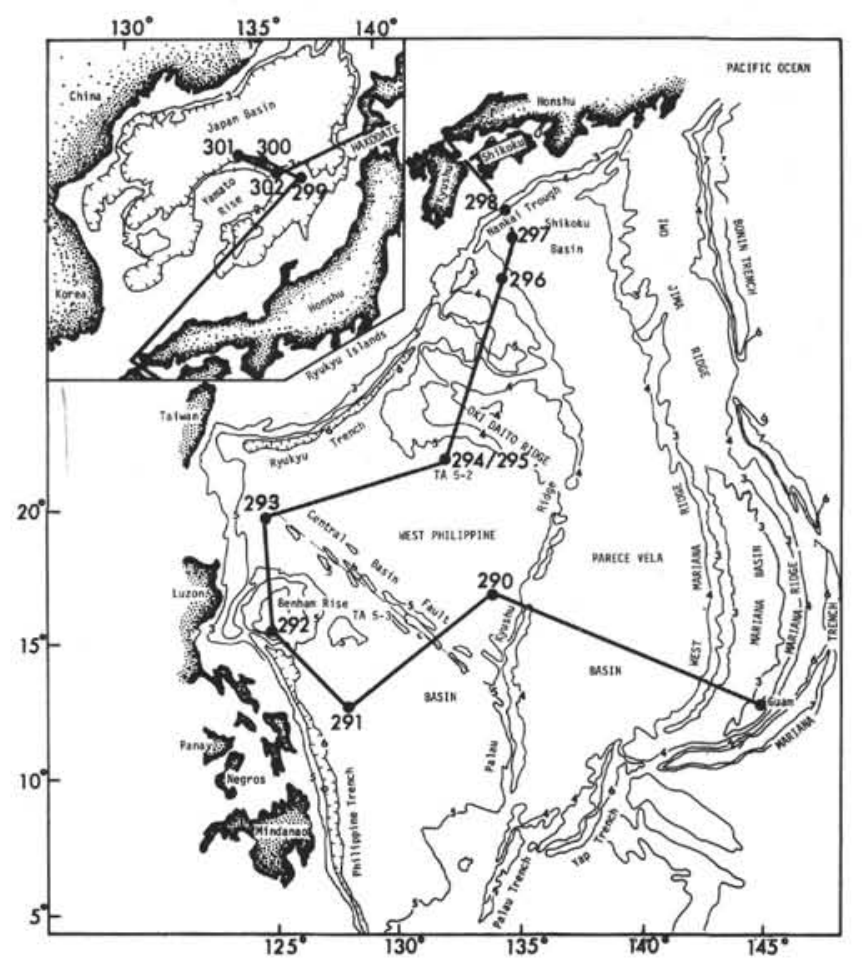

Figure 1. Location map for Leg 31 drilling sites.

samples, 28 were dry-sieved to obtain the $>0.0625-\mathrm{mm}$ $(4 \phi)$ fraction for detailed petrographic analysis. This fraction was then mounted in epoxy and made into thin sections for point counting. The slides were stained with a concentrated sodium cobaltinitrite solution to enable distinction of potassium feldspars. The point counts 
consist of 400-700 grains per slide (Table 1). Pointcounting results are plotted on a triangular diagram with end members of quartz + chert (Q), total feldspar $(\mathrm{F})$, and lithic fragments $(\mathrm{L})$. In addition, the ratios $\mathrm{V} / \mathrm{L}$ (volcanic lithic fragments to total lithic fragments), $\mathrm{P} / \mathrm{F}$ (plagioclase feldspar to total feldspar), and $\mathrm{M} / \mathrm{L}$ (metamorphic lithic fragments to total lithic fragments) are summarized in Table 1. These secondary parameters serve as additional indicators of provenance as outlined by Dickinson (1970) and discussed in detail below.

While the distinction between the various detrital grains is generally straightforward, certain criteria were used to distinguish between the wide range of aphanitic lithic fragments. Characteristic textures and mineralogies of the lithic fragment classifications became increasingly more obscure with both finer grain size and greater alteration. Preserved felsitic or microlitic textures in very fine-grained volcano-plutonic rock fragments generally enabled their differentiation. Devitrification of glass in many fragments produced a microcrystalline aggregate often resembling chert. These fragments, however, characteristically retained small amounts of potassium feldspar stain whereas "true" chert fragments did not. Sedimentary rock fragments of questionable texture were commonly distinguished from very fine-grained volcanic rock fragments by their distinct orientation of length-slow clay particles. Synsedimentary rip-up clasts resembled true sedimentary rock fragments, but characteristically included numerous unaltered Radiolaria, sponge, and foraminifera fragments, were generally more angular, and were commonly of a size conspicuously inconsistent with the detrital grains in the sample. Low-grade metamorphic rock fragments were the most difficult to differentiate from volcanic and sedimentary fragments due to their transitional nature.

\section{GRAIN SIZE}

Grain-size data are represented as cumulative frequency curves for representative samples of each site studied. Since this petrographic analysis was made on the $>0.0625-\mathrm{mm}(4 \phi)$ portion of all samples, these curves are presented to provide a graphic picture of the overall grain-size distribution. In each case, curves corresponding to the samples of this study are included when available, with additional curves displayed to show characteristic trends of each site. In addition, the grain-size range of each point-counted thin section was visually estimated (Table 1).

The cumulative curves (Figures 2-6) show that the counted samples include from 5\% to more than $30 \%$ clay-size matrix, of primary origin. The visual scans indicate that the grain-size range of point-counted samples varies from very fine to fine, to coarse to very coarse sand. The most frequently occurring grain-size range among the point-counted samples is very fine to medium sand.

\section{SITE 293}

Site 293 was drilled in the northwest corner of the West Philippine Basin (Figure 1) at the edge of a sedimentary apron presently receiving detritus from the island of Luzon (Karig, 1973). Five samples were analyzed from a 115-meter-thick layer consisting of clay with sandy silt and silt intercalations at 98 to 212 meters below sea floor (Cores 2-6). This layer is overlain by a sandy silt layer from which only a trace amount of material was obtained by punch core and is underlain by a 176-meter-thick series of sediment. The samples are all of early Pleistocene age.

Representative cumulative curves for Site 293 are shown in Figure 2. A fining with depth is apparent and is consistent with the overall fining with depth observed during shipboard operations.

The average composition of the point-counted samples is $\mathrm{Q}_{5} \mathrm{~F}_{17} \mathrm{~L}_{78}$ (Figure 7) with an average $\mathrm{V} / \mathrm{L}$ ratio of $0.72(\sigma=0.32)$. Only in Sample $293-5-4,114-116 \mathrm{~cm}$ do sedimentary rock fragments dominate over volcanic rock fragments (Table 1). This sample, however, consists of $52 \%$ wood fragments. Moreover, the distinction between actual detrital sedimentary rock fragments and similar fragments resulting from drilling operations is especially arbitrary here. Plagioclase feldspar is more abundant than potassium feldspar in all samples with a $\mathrm{P} / \mathrm{F}$ ratio ranging from 0.75 to 0.99 (average $=0.93, \sigma=$ $0.10)$. The $0.75 \mathrm{P} / \mathrm{F}$ ratio is for Sample 293-5-4, 114-116 $\mathrm{cm}$ in which a small number of feldspar grains were present (Table 1).

Samples 293-3-1, 69-70 $\mathrm{cm}$ and 293-4-2, 135-137 cm contained the coarsest rock fragments (very coarse sand) encountered. The volcanic rock fragments provided unique examples of texture and composition, generally being classified as andesitic to dacitic volcanics. The heavy mineral assemblages include hypersthene, olivine, hornblende, and clinopyroxene.

The sedimentary apron into which Site 293 was drilled presently receives detritus from Luzon. This source area indicates a much more varied assemblage than that observed in this study. The presence of numerous plant fragments in Sample 293-5-4, 114-116 cm, and the occurrence of sedimentary to metasedimentary lithic fragments implies a terrigenous source for some of these sediments.

The paucity of metamorphic lithic fragments and low percentage of sedimentary rock fragments in the samples studied could, in part, be a function of differential durability of the different fragments during fluvial transport (Cameron and Blatt, 1971). However, it may be a reflection of the extreme volcano-tectonic activity of the Luzon-Taiwan region from middle Tertiary to the present (Karig, 1973).

\section{SITE 297}

Six samples from Site 297, drilled in the westernmost corner of the Shikoku Basin (Figure 1), have been analyzed. The samples are from a 247 -meter-thick turbidite sequence penetrated from 330 to 570 meters below sea floor (Cores 14 through 22). The samples studied range from early Pliocene to middle (?) Miocene.

The composition of the samples average $\mathrm{Q}_{14} \mathrm{~F}_{15} \mathrm{~L}_{71}$ (Figure 7); the lithic fragments being predominantly sedimentary rock fragments in all samples (Figure 8). The $\mathrm{V} / \mathrm{L}$ ratio is thus quite low with an average of 0.09 $(\sigma=0.10)$. These sedimentary rock fragments are 
TABLE 1

Tabulated Point-Count Data for Some Marginal Basin Sands Recovered on Leg 3

\begin{tabular}{|c|c|c|c|c|c|c|c|c|c|c|c|c|c|c|c|c|c|}
\hline $\begin{array}{c}\text { Sample } \\
\text { (Interval in } \mathrm{cm} \text { ) }\end{array}$ & $\begin{array}{c}\text { Visual Estimate } \\
\text { of Grain } \\
\text { Size Range }\end{array}$ & VRF & SRF & MRF & $\mathrm{K}-\mathrm{Fe}$ & Plag. & Quar. & Chert & Mica & Heavies & Other & $Q^{a}$ & $\mathrm{~F}^{\mathrm{a}}$ & $\mathrm{L}^{\mathrm{a}}$ & $\mathrm{V} / \mathrm{L}$ & $\mathrm{P} / \mathrm{F}$ & $\mathrm{M} / \mathrm{L}$ \\
\hline $293-3-1,69-71$ & Coarse-V. Coarse & 0.70 & 0.02 & - & $\mathrm{T}$ & 0.14 & 0.10 & - & - & 0.04 & - & 10 & 15 & 75 & 0.97 & 0.99 & - \\
\hline $293-4-2,14-16$ & V. Fine-Fine & 0.53 & 0.22 & - & $\mathrm{T}$ & 0.15 & 0.03 & - & 0.02 & 0.04 & - & 04 & 17 & 79 & 0.71 & 0.97 & - \\
\hline $293-4-2,135-137$ & V. Fine-Coarse & 0.55 & 0.01 & - & $\mathrm{T}$ & 0.24 & 0.04 & - & - & 0.15 & - & 05 & 28 & 67 & 0.98 & 0.98 & - \\
\hline $293-5-4,114-116$ & V. Fine-Fine & 0.08 & 0.35 & - & $\mathrm{T}$ & 0.01 & $\mathrm{~T}$ & 0.01 & 0.01 & $\mathrm{~T}$ & 0.52 & 03 & 04 & 93 & 0.18 & 0.75 & - \\
\hline $293-6-2,131-133$ & V. Fine-Fine & 0.51 & 0.15 & 0.01 & 0.01 & 0.18 & 0.02 & - & 0.03 & 0.10 & - & 02 & 21 & 77 & 0.76 & 0.97 & 0.01 \\
\hline $297-15-4,149-150$ & V. Fine-Med. & 0.03 & 0.67 & - & 0.03 & 0.13 & 0.13 & 0.01 & $\mathrm{~T}$ & - & - & 14 & 16 & 70 & 0.04 & 0.84 & - \\
\hline $297-16-3,120-122$ & V. Fine-Med. & $\mathrm{T}$ & 0.60 & 0.05 & 0.03 & 0.10 & 0.21 & $\mathrm{~T}$ & - & $\mathrm{T}$ & - & 21 & 13 & 66 & 0.01 & 0.76 & 0.08 \\
\hline $297-18-1,148-150$ & V. Fine-Med. & 0.01 & 0.60 & 0.06 & 0.04 & 0.11 & 0.14 & 0.01 & $\mathrm{~T}$ & 0.03 & - & 16 & 16 & 68 & 0.02 & 0.71 & 0.09 \\
\hline $297-22-2,59-61$ & V. Fine-Med. & 0.02 & 0.76 & $\mathrm{~T}$ & $\mathrm{~T}$ & 0.03 & 0.03 & $\mathrm{~T}$ & 0.04 & $\mathrm{~T}$ & 0.09 & 04 & 04 & 92 & 0.03 & 0.88 & - \\
\hline $297-22-2,88-90$ & V. Fine-Coarse & 0.15 & 0.40 & - & 0.03 & 0.19 & 0.14 & $\mathrm{~T}$ & 0.03 & 0.06 & - & 16 & 24 & 60 & 0.27 & 0.88 & - \\
\hline $297-22-3,129-131$ & V. Fine-Coarse & 0.09 & 0.47 & $\mathrm{~T}$ & 0.03 & 0.10 & 0.08 & $\mathrm{~T}$ & 0.03 & 0.02 & 0.17 & 11 & 17 & 72 & 0.16 & 0.79 & - \\
\hline $298 \mathrm{~A}-1-1,130-132$ & V. Fine-Fine & 0.35 & 0.30 & - & 0.05 & 0.09 & 0.11 & 0.01 & 0.03 & 0.07 & - & 13 & 15 & 72 & 0.54 & 0.65 & - \\
\hline $298-2-1,148-150$ & Fine-Coarse & 0.18 & 0.41 & - & 0.03 & 0.14 & 0.14 & 0.02 & $\mathrm{~T}$ & 0.07 & - & 17 & 19 & 64 & 0.31 & 0.85 & - \\
\hline $298-2-3,46-48$ & V. Fine-Med. & 0.19 & 0.33 & 0.05 & 0.03 & 0.12 & 0.14 & 0.03 & 0.01 & 0.09 & - & 19 & 18 & 63 & 0.34 & 0.78 & 0.09 \\
\hline $298-4-3,146-148$ & V. Fine-Med. & 0.10 & 0.42 & 0.03 & 0.03 & 0.19 & 0.15 & 0.04 & 0.01 & 0.04 & - & 19 & 24 & 57 & 0.18 & 0.86 & 0.05 \\
\hline 298-5-2, 91-93 & V. Fine-Coarse & 0.18 & 0.45 & 0.04 & 0.02 & 0.13 & 0.09 & 0.02 & 0.03 & 0.05 & - & 12 & 16 & 72 & 0.27 & 0.88 & 0.06 \\
\hline $298-14-1,66-67$ & V. Fine-Coarse & 0.25 & 0.46 & 0.03 & 0.01 & 0.11 & 0.06 & 0.04 & 0.01 & 0.03 & - & 11 & 13 & 76 & 0.34 & 0.88 & 0.04 \\
\hline $298-14-3,112-114$ & V. Fine-Med. & 0.09 & 0.41 & 0.05 & 0.05 & 0.11 & 0.18 & 0.04 & 0.01 & 0.06 & - & 23 & 17 & 60 & 0.17 & 0.67 & 0.09 \\
\hline $299-17-2,70-72$ & V. Fine-Med. & 0.44 & 0.11 & - & 0.05 & 0.17 & 0.12 & 0.03 & 0.01 & 0.06 & - & 16 & 25 & 59 & 0.79 & 0.76 & - \\
\hline $299-17-2,145-146$ & V. Fine-Med. & 0.51 & 0.11 & - & 0.02 & 0.15 & 0.10 & 0.03 & 0.01 & 0.07 & - & 15 & 18 & 67 & 0.82 & 0.88 & - \\
\hline $299-17-4,41-42$ & V. Fine-Med. & 0.55 & 0.11 & - & 0.05 & 0.14 & 0.07 & 0.03 & 0.02 & 0.04 & - & 10 & 19 & 71 & 0.83 & 0.75 & - \\
\hline $299-35-1,70-72$ & V. Fine-Fine & 0.78 & 0.08 & - & 0.02 & 0.06 & 0.04 & $\mathrm{~T}$ & $\mathrm{~T}$ & 0.01 & - & 05 & 08 & 87 & 0.91 & 0.75 & - \\
\hline $299-35-1,113-115$ & V. Fine-Fine & 0.87 & 0.02 & 0.01 & $\mathrm{~T}$ & 0.03 & 0.03 & $\mathrm{~T}$ & $\mathrm{~T}$ & 0.01 & - & 04 & 04 & 92 & 0.96 & 0.79 & 0.01 \\
\hline $299-37-2,15-17$ & V. Fine-Med. & 0.19 & 0.50 & 0.01 & 0.04 & 0.08 & 0.12 & 0.01 & 0.03 & 0.01 & - & 14 & 13 & 73 & 0.27 & 0.66 & 0.01 \\
\hline $301-5-3,130-132$ & V. Fine-Fine & 0.04 & 0.16 & 0.06 & 0.10 & 0.31 & 0.20 & 0.03 & 0.04 & 0.07 & - & 26 & 46 & 28 & 0.14 & 0.76 & 0.23 \\
\hline $301-7-1,135-137$ & V. Fine-Med. & 0.04 & 0.07 & 0.17 & 0.09 & 0.27 & 0.23 & 0.01 & 0.05 & 0.07 & - & 27 & 41 & 32 & 0.13 & 0.75 & 0.61 \\
\hline $301-8-1,63-64$ & V. Fine-Med. & 0.20 & - & 0.02 & 0.12 & 0.25 & 0.35 & $\mathrm{~T}$ & 0.02 & 0.03 & - & 38 & 39 & 23 & 0.91 & 0.67 & 0.09 \\
\hline $301-11-1,149-150$ & V. Fine-Fine & 0.16 & 0.02 & - & 0.07 & 0.24 & 0.29 & - & 0.14 & 0.08 & - & 37 & 40 & 23 & 0.91 & 0.76 & \\
\hline
\end{tabular}

${ }^{\text {a }}$ Reflect percentages as plotted in Figure 7 . 


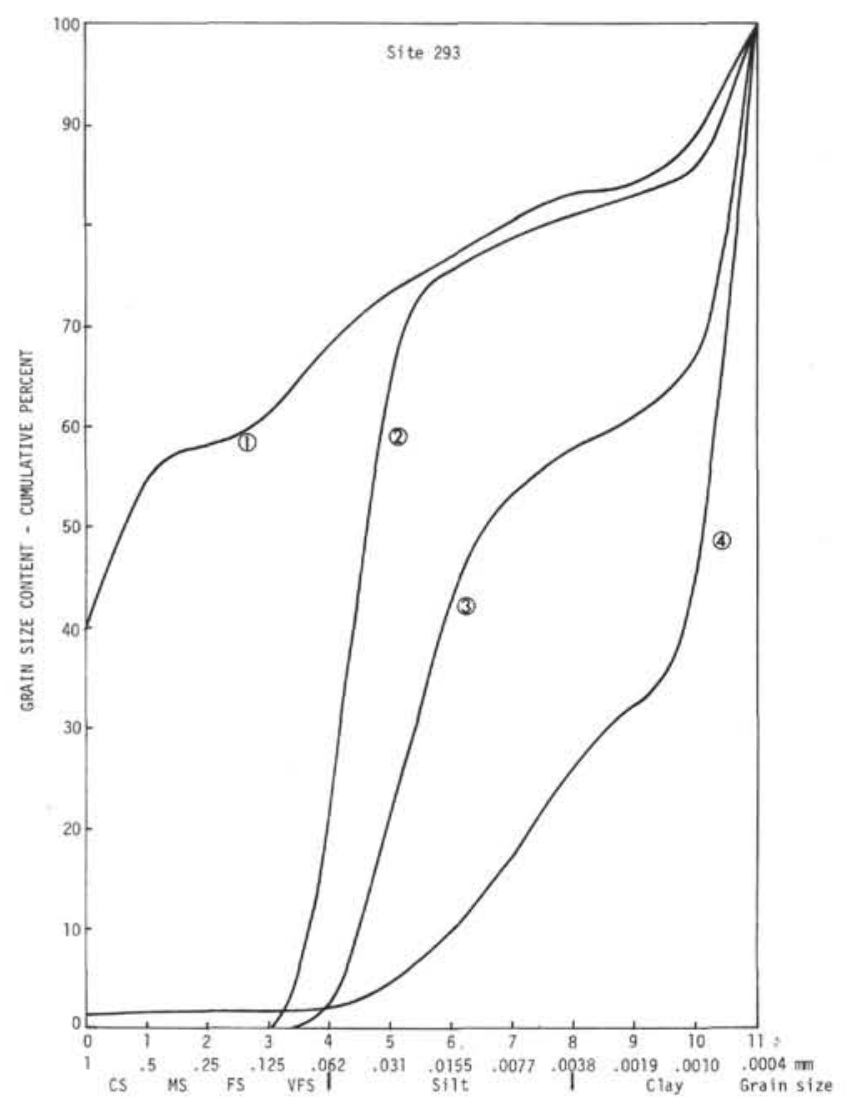

Figure 2. Representative cumulative grain size curves for Site 293. Curves 1 and 3 correspond to point-counted Samples 293-3-1, 69-71 cm and 293-5-4, 114-116 cm, respectively. Curve 2 is from $293-3-5,48-50 \mathrm{~cm}$ and curve 4 is from $293-7-2,13-15 \mathrm{~cm}$.

predominantly well-rounded, equant to elongate grains containing quartz and feldspar in an argillaceous matrix. Mica included in some fragments is occasionally deformed due to compaction. The argillaceous matrix commonly shows well-oriented, length-slow grains, but evidence of bedding surfaces is absent. Plagioclase is dominant over potassium feldspar, shown by a $\mathrm{P} / \mathrm{F}$ ratio of $0.81(\sigma=0.07)$. The plagioclase feldspar occurs both as highly altered and unaltered grains with relict twinning commonly observed in the more altered grains. Samples $297-22-2,59-61 \mathrm{~cm}$ and 297-22-3, 129-131 cm consist of $9 \%$ and $17 \%$, respectively, of plant debris extensively replaced by pyrite.

Recognizable metamorphic (metasedimentary?) grains are not abundant, but are present in four of the six samples in amounts ranging from $<1 \%$ to $6 \%$ of all lithic fragments. These grains are predominantly polycrystalline quartz grains, commonly with elongate crystal domains, and well-sutured grain boundaries. The distinction of slate and phyllite fragments from sedimentary rock fragments is quite arbitrary due to the transitional nature of these two classes, especially in the size fraction used.

The low V/L ratio, the high percentage of sedimentary rock fragments, and the presence of plant debris indicate that the sands were derived from a continental source area with sedimentary affinities. Site 297 lies

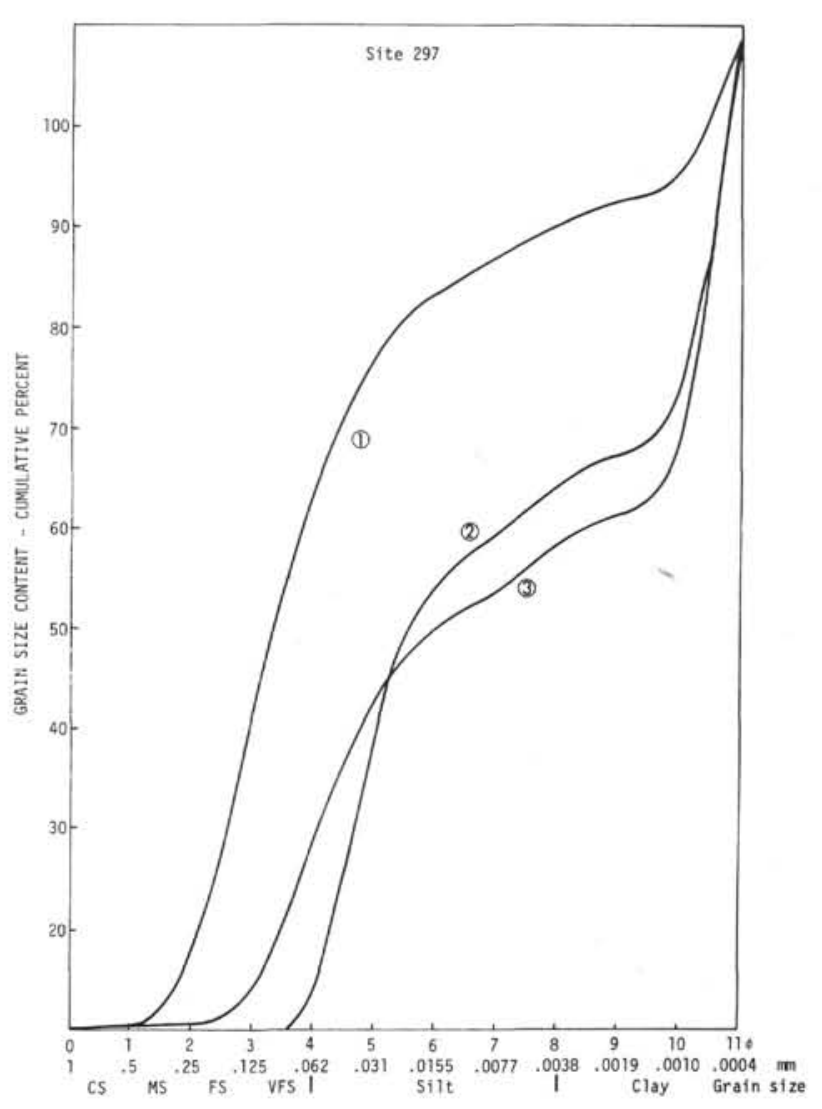

Figure 3. Representative cumulative curves for Site 297.

Curve 2 corresponds to point-counted Sample 297-22-2, $59-61 \mathrm{~cm}$. Curve 1 is from 297-17-2,100-102 cm and curve 3 is from $297-23-4,76-78 \mathrm{~cm}$.

south of Shikoku and Kyushu islands. These islands lie within the outer belt of the Ryukyu arc (Minato et al., 1965 , p. 283) which is composed primarily of Mesozoic and Cenozoic sedimentary rocks. No doubt much of the detritus deposited at Site 297 was derived from this predominantly sedimentary source terrain.

\section{SITE 298}

Site 298 was located about $100 \mathrm{~km}$ northwest of Site 297 on the inner wall of Nankai Trough off Shikoku Island (Figure 1). The section drilled consists of 611 meters of interbedded hemipelagic muds and turbidity current deposits of Recent (?) to early Pleistocene age.

Seven samples were analyzed with an average composition of $\mathrm{Q}_{16} \mathrm{~F}_{17} \mathrm{~L}_{67}$ (Figure 7). Sedimentary rock fragments are the dominant lithic fragments except in Sample 298A-1-1, 130-132 cm in which volcanic rock fragments are slightly more abundant. The average $\mathrm{V} / \mathrm{L}$ ratio is $0.31(\sigma=0.12)$. Plagioclase feldspar is more abundant than potassium feldspar with an average $\mathrm{P} / \mathrm{F}$ ratio of $0.80(\sigma=0.10)$.

The sedimentary rock fragments are well-rounded argillaceous fragments with distinct orientation of clays and micas. Deformation of mica flakes due to compaction is common. The fragments, as in Site 297, are gradational to low-grade schists and phyllites. 


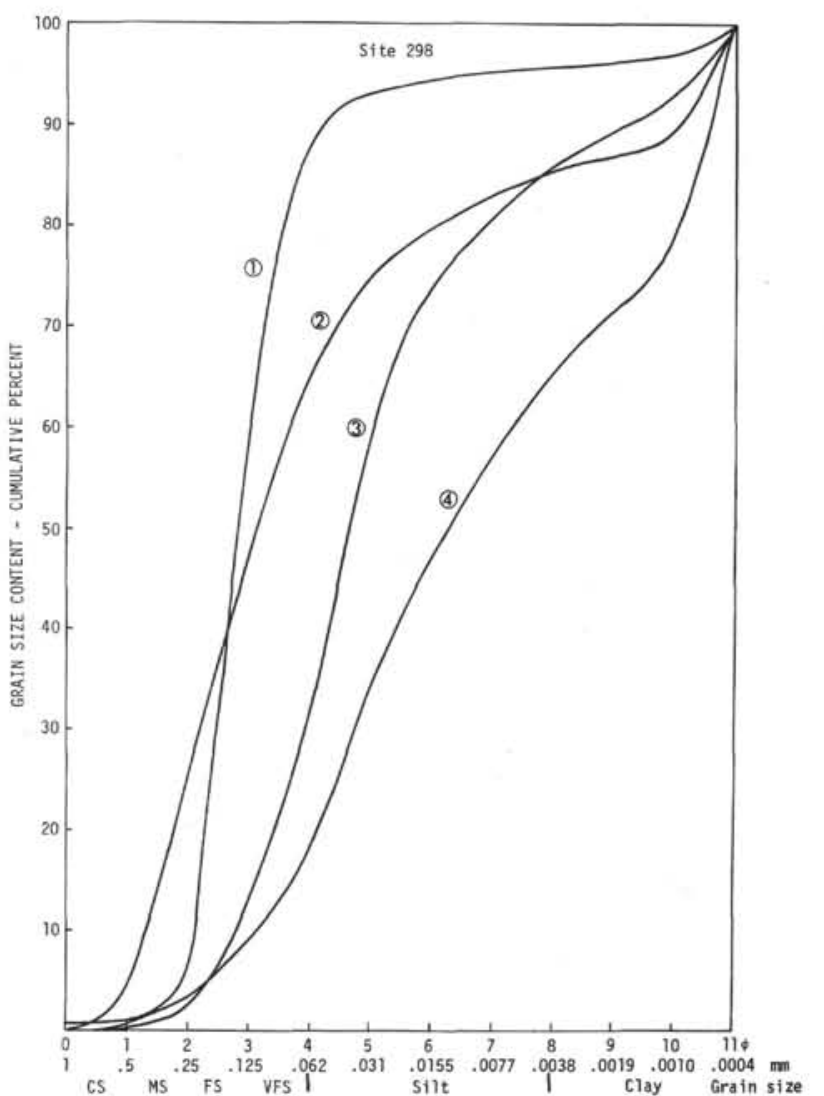

Figure 4. Representative cumulative curves for Site 298. Curves 1 and 2 correspond to point-counted Samples 298 A-1-1, 130-132 cm and 298-14-3, 112-114 cm, respectively. Curve 3 is from 298-12-5, 64-66 cm and curve 4 is from $298-12-5,77-79 \mathrm{~cm}$.

Sites 297 and 298 contain the most varied assemblages of detrital grains observed during this study. The similarities in their compositions indicate a common source area. However, two notable differences between the two sites are the distinct $\mathrm{V} / \mathrm{L}$ ratios $(0.31$ for 298 ; 0.09 for 297) and the consistently higher percentage of heavy minerals in the samples from Site 298.

\section{SITE 299}

Site 299 was drilled in the northeast Yamato Basin (Figure 1) in the Sea of Japan. The 532-meter sequence consists mostly of clayey silt and silty clay. Various intercalations of more sandy or more clayey sediment, volcanic ash beds, and carbonate-rich sediments were noted. The samples studied range in age from early Pleistocene to Pliocene(?).

The average composition of the sediments is $\mathrm{Q}_{11} \mathrm{~F}_{15} \mathrm{~L}_{74}$ (Figure 7 and Table 1); lithic fragments comprise from $55 \%$ to $90 \%$ of all grains counted. Volcanic rock fragments are predominant in all samples except one (299-37-2, 15-17 cm). Two samples from Core 35 (299-35-1, 70-72 cm and 299-35-1, 113-115 cm) are composed of $64 \%$ and $75 \%$ volcanic glass shards, respectively. Plagioclase feldspar is dominant over potassium feldspar in all samples (mean $\mathrm{P} / \mathrm{F}=0.77, \sigma=0.07$ ).

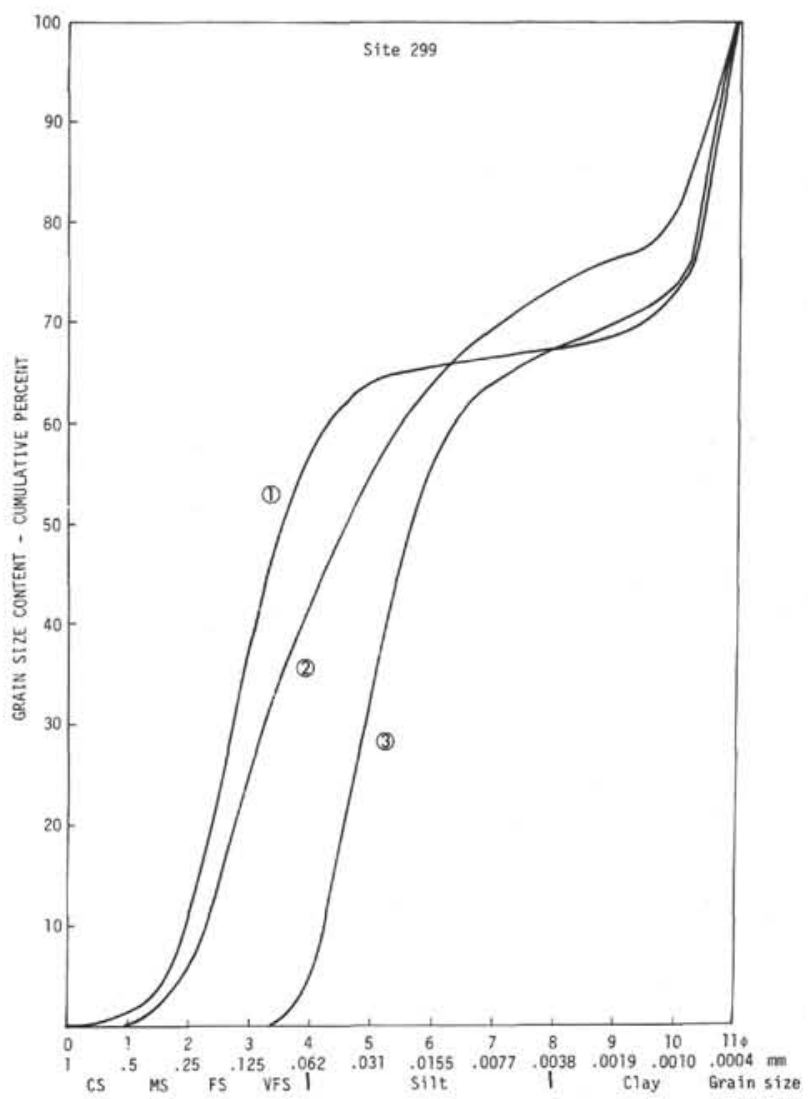

Figure 5. Representative cumulative curves for Site 299. Curve 1 corresponds to point-counted Sample 299-17-4, $41-42 \mathrm{~cm}$. Curve 2 is from 299-38-5, 129-131 cm and curve 3 is from $299-13-3,72-74 \mathrm{~cm}$.

The volcanic rock fragments (other than glass shards) are andesitic to dacitic, reflecting their source of the inner belts of the northeast and southwest Japan arcs (Minato et al., 1965). The tectonic and volcanic activity of the late Tertiary in the northwest Honshu area (Minato et al., 1965) produced an extensive area of late Tertiary volcanic and plutonic material, which apparently supplied detritus to the Yamato Basin.

Sample 299-37-2, 15-17 cm (Table 1) contains an anomalously high percentage of sedimentary rock fragments $(50 \%)$. This sand is the oldest sample (Pliocene ?) from Site 299 and may represent a volcanic minima in the development of northwest Honshu.

\section{SITE 301}

Site 301 was drilled in the east central portion of the Japan Basin (Figure 1). The stratigraphic section consists of 240.5 meters (Cores 1-7) of late Pleistocene to early Pleistocene clay and silty-clay with interbedded silt, sand, and silty-sand beds of probable turbidite origin. This unit is underlain by 256 meters (Cores 8-20) of clayey diatomite or diatomaceous clay-stone with a few sandy interbeds of late Pliocene to late Miocene age. Samples from both units were analyzed in this study. 


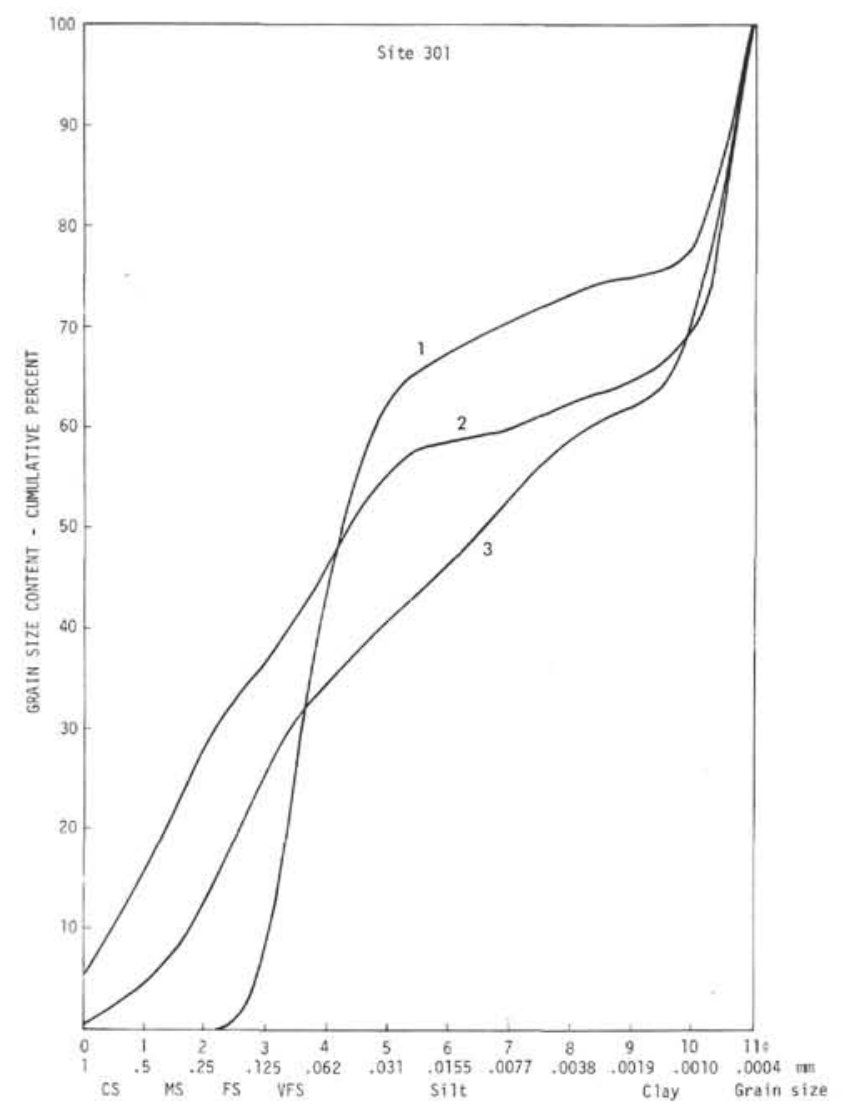

Figure 6. Representative cumulative curves for Site 301. Curves 1 and 2 correspond to point-counted Samples $301-5-3,130-132 \mathrm{~cm}$ and $301-7-1,135-137 \mathrm{~cm}$, respectively. Curve 3 is from $301-18-2,121-123 \mathrm{~cm}$.

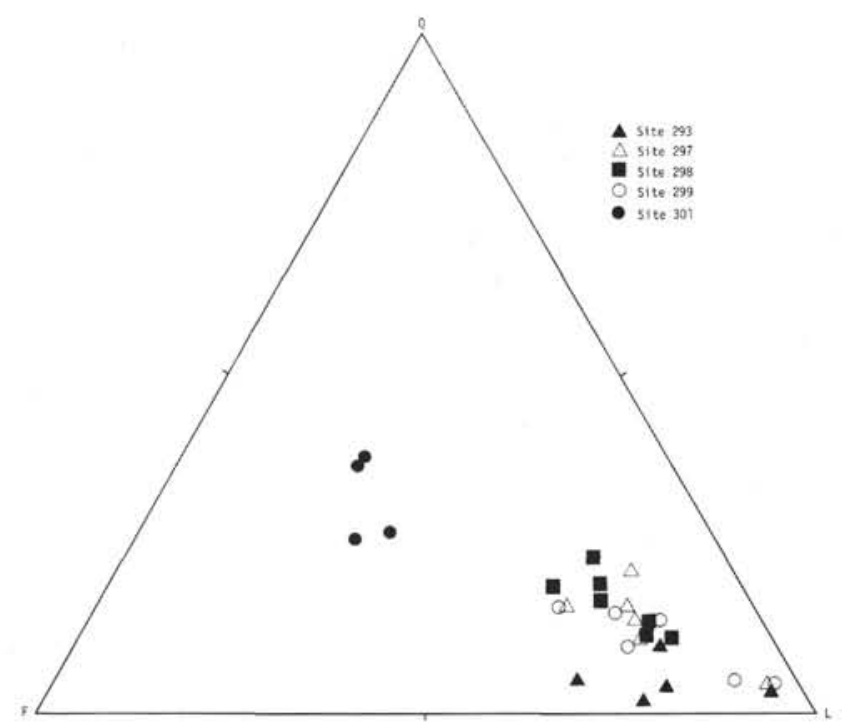

Figure 7. Ternary plot of quartz plus chert $(Q)$, total lithic fragments, $(L)$, and feldspar $(F)$. Note the distinct enrichment of the Site 301 sands in quartz plus chert and feldspar.

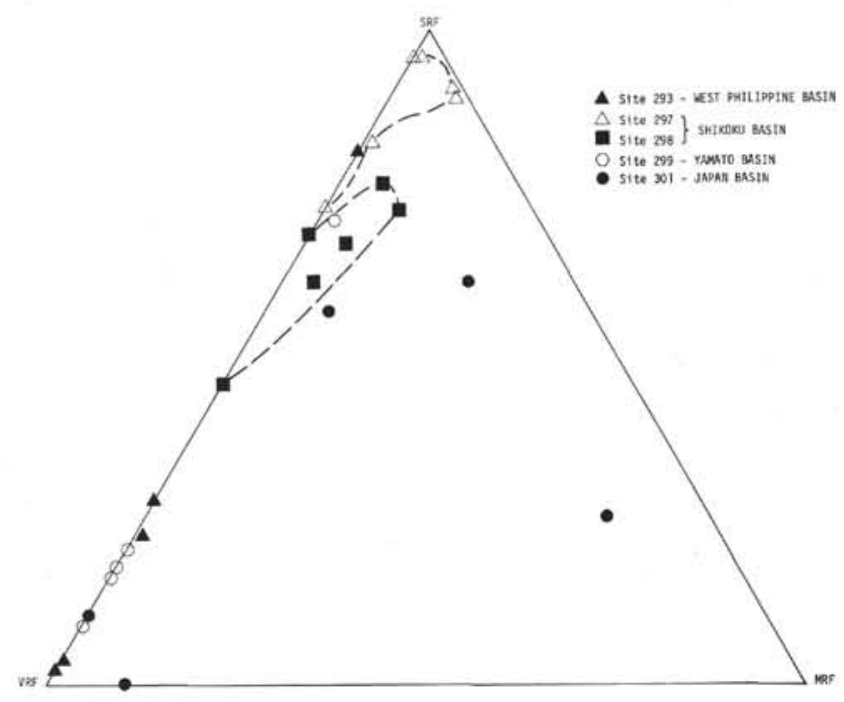

Figure 8. Ternary plot of sedimentary rock fragments $(S R F)$, metamorphic rock fragments (MRF), and volcanic rock fragments (VRF). Note the clustering of Site 297 and 298 compositions near SRF pole. Also note that most Site 301 compositions are enriched in metamorphic rock fragments.

The samples are significantly lower in percent lithic fragments than those from the other sites. The average composition is $\mathrm{Q}_{32} \mathrm{~F}_{42} \mathrm{~L}_{26}$ (Figures 7 and Table 1). The average $\mathrm{V} / \mathrm{L}$ ratio is $0.52(\sigma=0.45)$ with notable differences between those samples from the upper, turbidite unit and those from the lower, diatomaceous unit (Table 1). Plagioclase feldspar is dominant over potassium feldspar with an average $\mathrm{P} / \mathrm{F}$ ratio of $0.74(\sigma$ $=0.04)$. Rip-up clasts became predominant with a noticeable increase in the lower unit. An increase in the degree of alteration of lithic fragments and feldspar grains with depth was also observed.

The influence of granitic rocks of the continental area to the west of the Japan Basin (Meng, 1970) is readily apparent in the Site 301 samples. The significant occurrence of microcline, myrmekite, and anhedral, strained quartz grains with abundant inclusions all reflect the granitic nature of the source area.

\section{DISCUSSION}

\section{Distinguishing Between the Sand Suites}

In the preceding portion of this paper sand compositions from various basins have been described and an attempt made to show how they reflect their source areas. Questions, however, may be raised as to how each of these sand suites is different, and by inference how could their source areas be distinguished.

The simple QFL plot (Figure 7) serves to differentiate the quartz and feldspathic-rich sands of the Japan Basin from those of all other localities. Sands of the West Philippine Basin, Shikoku Basin, and Yamato Basin, which are consistently rich in lithic fragments, may be most clearly separated by the V/L ratios (Figure 9). Clearly, the samples from the West Philippine and 


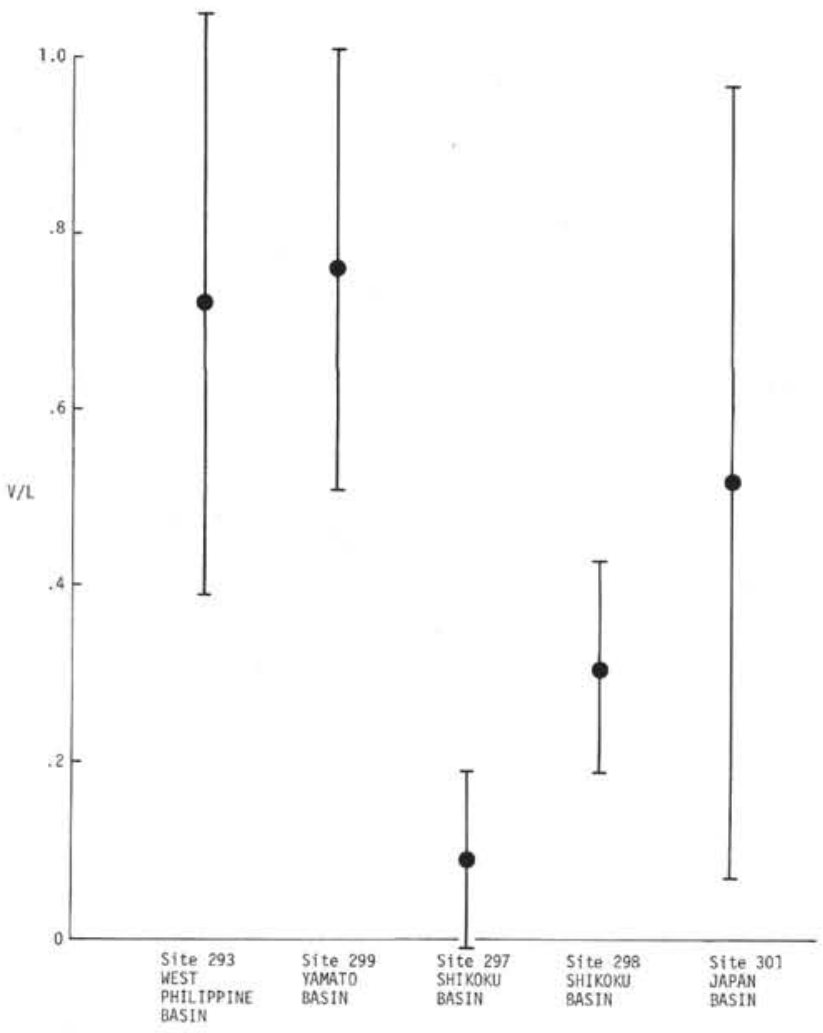

Figure 9. Plot of mean $V / L$ (volcanic rock fragments/total lithic fragments) versus location. Error bar equals standard deviation. Note relative identity of $V / L$ ratios for Sites 293 and 299, and Sites 297 and 298.
Yamato basins (Sites 293 and 299, respectively) are moderately to strongly enriched in volcanic rock fragments relative to those from the Shikoku Basin (Sites 297 and 298). It is not possible to compositionally separate the sands from Sites 293 and 299, based on available data. The sedimentary rock fragment-rich samples from the Shikoku Basin (Sites 297 and 298) form adjacent clusters on the triangular plot of rock fragments (Figure 8).

The relative increase in metamorphic rock fragments serves to discriminate the sands of the Japan Basin from all other localities. Moreover, the metamorphic rock fragments from Site 301 are petrographically distinct, being more coarse grained than those from the other marginal basins.

\section{Trends in Sand Composition}

Marginal basin complexes of the northwestern Pacific may be subdivided into interior basins which border the continental mass, exterior basins which are on the landward side of the frontal arc, and transitional basins lying between the geographic extremes of interior and exterior basins (Figure 10). Sands have been studied from one interior basin (Japan Basin, Site 301); one transitional basin (West Philippine Basin, Site 293); and one exterior basin (Shikoku Basin, Sites 297 and 298). The Yamato Basin may be considered as either an exterior or transitional basin making the classification of data (Site 299) from this basin equivocal.

Marginal basins apparently form by the splitting and migration of a volcanic arc away from a continental margin (Karig, 1971). It is assumed that the frequency of

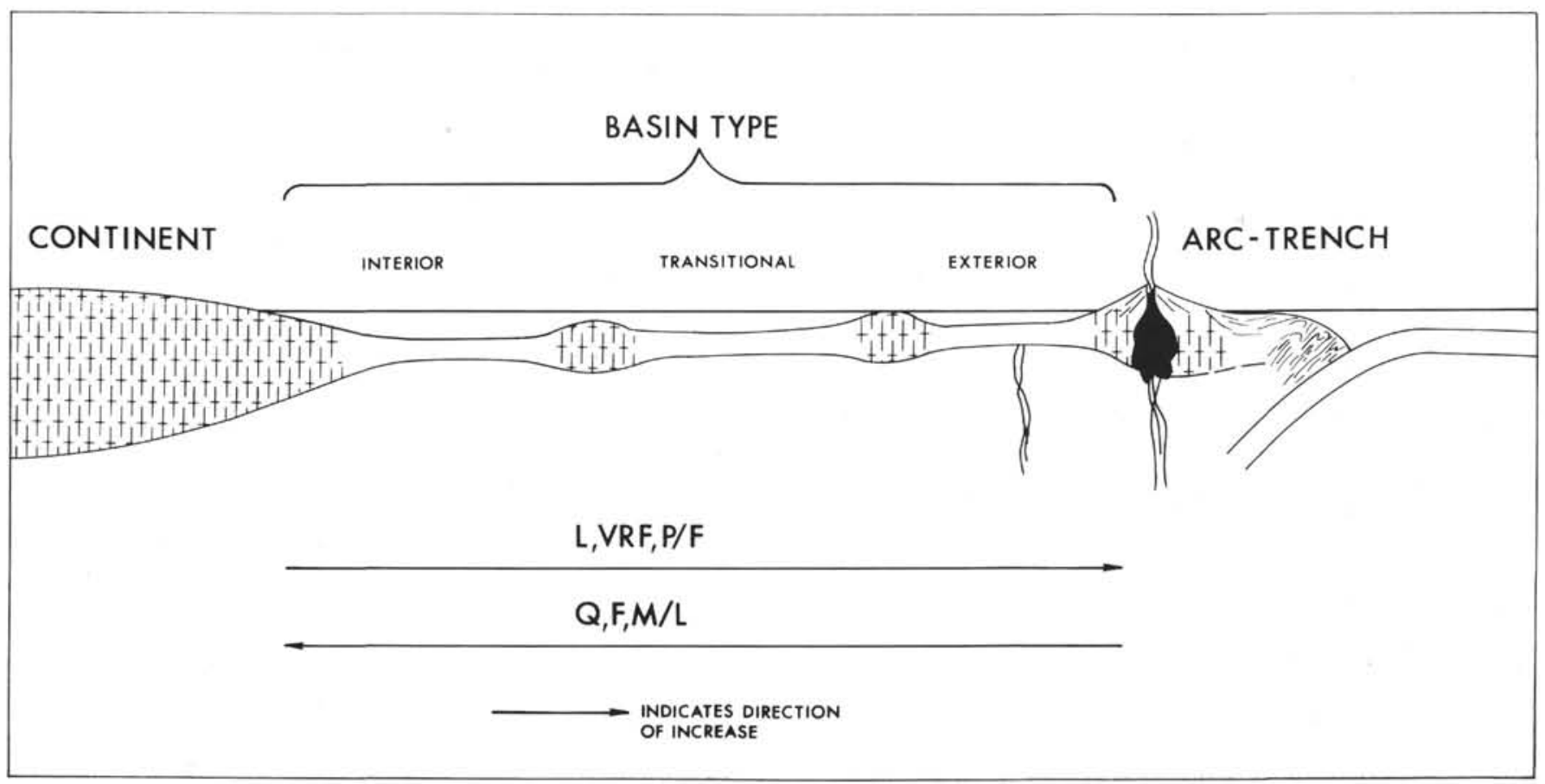

Figure 10. Schematic cross-section of marginal basin complex. Portions of complex subdivided into interior, transitional, and exterior basins. Expected variation in sand composition given below schematic cross-section. L equals total lithic fragments; $V R F$ designates volcanic rock fragments; $P / F$ indicates ratio of plagioclase over total feldspar; $Q$ and $F$ equal quartz plus chert and feldspar, respectively; $M / L$ represents ratio of metamorphic rock fragments over total lithic fragments. 
volcanism decreases from the frontal arc towards the continent, and that influence of the parental continental margin as a sediment source increases away from the frontal arc and toward the continent. Based on the above boundary conditions, it is possible to outline a simple model of sand petrology across an existing series of marginal basins.

The total percent of lithic material should increase from the interior to exterior basin due to the significant quantities of fine-grained volcanic deposits and accreted sedimentary rocks bordering the transitional and exterior basins. Alternatively, sands will become more quartz and feldspar-rich in the interior basin due to the influence of the continental basement terrain. Likewise, the absolute abundance of volcanic rock fragments should increase towards the exterior basin. The ratio of metamorphic to total lithic fragments would likely increase in the interior basin due to the proximity of old crystalline basement terrain of the continent. Finally, the $\mathrm{P} / \mathrm{F}$ ratio should decrease away from the exterior toward the interior basins as the sediments begin to record potassium feldspar from the continental crystalline basement terrain.

The preceding model considers compositional variations of sand over a series of basins at a given time after they have formed. A more complete model should integrate the expected variations over time for an evolving marginal basin complex. For example, a basin directly adjacent to the continent should be under the influence of both the frontal arc and continent when it formed. However, it would receive an increasing portion of its sediment from the continent after successive marginal basins have developed on its seaward margin. Therefore, a vertical sequence should show a decreasing volcanic provenance.

The data herein provide a partial test of the above model. First of all, the interior basin (Japan Basin, Site $301)$ includes sands that are dramatically enriched in quartz and feldspar relative to the lithic-rich sands of transitional and external basins (West Philippine Basin, Site 293; Shikoku Basin, Sites 297 and 298; and Yamato Basin, Site 299). The external and transitional basins show equally high percentages of lithic fragments, but variable percentages of volcanic rock fragments. The average percentage of volcanic rock fragments for external and transitional basins (31\%) is significantly greater than that observed in the internal basin $(11 \%)$. Similarly the $\mathrm{P} / \mathrm{F}$ ratios of the external and transitional basins are variable, but average higher than the $\mathrm{P} / \mathrm{F}$ ratio of the interior basin. The $M / L$ ratio of the interior basin is significantly higher than those of the transitional and external basins. In summary, the predictions of the model hold for distinguishing between internal and transitional or external basins, but not for separating the deposits of the transitional and external basins.

The limited age span of the point-counted sands (predominantly Pliocene and Pleistocene) prevents a significant test of any expected time variations within marginal basins. The data and derived trends on sand composition presented in this paper hopefully will find application in interpreting the stratigraphic record. However, an absolute comparison of this data to ancient rocks should take into consideration the possible effects of diagenesis and low-grade metamorphism in reducing the percentage of lithic fragments (Cummins, 1962).

\section{ACKNOWLEDGMENTS}

The grain-size analyses presented in this paper were completed at the Deep Sea Drilling Project Lab, supervised by G. Bode.

We thank Ken Cameron and Robert Garrison for advice. Acknowledgment is made to the donors of the Petroleum Research Fund, American Chemical Society (Grant No. 2483G3) and the University of California for support of our laboratory studies.

\section{REFERENCES}

Cameron, K.L. and Blatt, H., 1971. Durabilities of sand size schist and "volcanic" rock fragments during fluvial transport, Elk Creek, Black Hills, South Dakota: J. Sediment Petrol., v. 41 , p. 565-576.

Cummins, W.A., 1962. The greywacke problem: Liverpool Manchr. Geol. J., v. 3, p. 51-72.

Dickinson, W. R., 1970. Interpreting detrital modes of greywacke and arkose: J. Sediment. Petrol., v. 40, p. 695707.

Dickinson, W.R. and Rich, E.I., 1972. Petrologic intervals and petrofacies in the Great Valley Sequence, Sacramento Valley, california: Geol. Soc. Am. Bull., v. 83, p. $3007-$ 05302 s4024.

Galloway, W.E., 1974. Deposition and diagenetic alteration of sandstone in northeast Pacific arc-Related basins: Implications for Greywacke Genesis: Geol. Soc. Am. Bull., v. 85 , p. 379-390.

Gilbert, W.G., 1973. Franciscan rocks near Sur Fault Zone, northern Santa Lucia Range, California: Geol. Soc. Am. Bull., v. 84 , p. 3317-3328.

Gilbert, W.G. and Dickinson, W.R., 1970. Stratigraphic variations in sandstone petrology, Great Valley Sequence, central California coast: Geol. Soc. Am. Bull., v. 81, p. 949-954.

Karig, D.E., 1971. Origin and development of marginal basins in the western Pacific: J. Geophys. Res., v. 76, p. 25422561.

, 1973. Plate convergence between the Philippines and the Ryukyu Islands: Marine Geol., v. 14, p. 153-168.

McLane, M., 1972. Sandstone: Secular trends in lithology in southwestern Montana: Science, v. 178, p. 502-504.

Meng, C.-y., 1970. Geologic map of the Republic of China: Chinese Petrol. Corp.

Minato, M., Gorai, M., and Hunahashi, M. (Eds.), 1965. The Geologic development of the Japanese Islands: Tokyo (Tsukiji Shokan Co.).

Moore, J. Casey, 1973. Cretaceous continental margin sedimentation, southwestern Alaska: Geol. Soc. Am. Bull., v. 84 , p. $595-614$.

Ojakangas, R.W., 1968. Cretaceous sedimentation, Sacramento Valley, California: Geol. Soc. Am. Bull., v. 79, p. 9731008.

1972. Archean volcanogenic greywackes of the Vermilion District, Northeastern Minnesota; Geol. Soc. Am. Bull., v. 83, p. 429-442.

Suppe, J., 1973. Geology of the Leech Lake Mountain-Ball Mountain Region, California: Univ. Calif. Publications in Geol. Sci., v. 107, p. 1-82.

Swe, W. and Dickinson, W.R., 1970. Sedimentation and thrusting of Late Mesozoic rocks in the Coast Ranges near Clear Lake, California: Geol. Soc. Am. Bull., v. 81, p. 165188. 